\title{
Modern Short Food Supply Chain, Good Agricultural Practices, and Sustainability: A Conceptual Framework and Case Study in Vietnam
}

\author{
Viet Hoang (D)
}

Citation: Hoang, V. Modern Short

Food Supply Chain, Good

Agricultural Practices, and

Sustainability: A Conceptual

Framework and Case Study in

Vietnam. Agronomy 2021, 11, 2408

https://doi.org/10.3390/

agronomy 11122408

Academic Editor: Peter J. Batt

Received: 27 October 2021

Accepted: 25 November 2021

Published: 26 November 2021

Publisher's Note: MDPI stays neutral with regard to jurisdictional claims in published maps and institutional affiliations.
School of Economics, University of Economics Ho Chi Minh City, Ho Chi Minh City 700000, Vietnam; viet.hoang@ueh.edu.vn

\begin{abstract}
The rapid increases in environmental pollution, urbanization, health concerns, and technological progress enhance the demand for greener, healthier, and fairer food production and consumption. The short food supply chain (SFSC) becomes one of the crucial solutions for these issues. This study aims to propose a conceptual framework of the SFSC, assess the short vegetable supply chain (SVSC) in Vietnam, identify its barriers and challenges, and explore interventions and support as key success factors of the SVSC by using both qualitative and quantitative methods. This study initially proposes the SFSC framework with six pillars and 28 indicators, this model is used to assess the SVSC. The results show that the SVSC brings various social, economic, and environmental benefits: First, it can increase farmers' income, employment, fairness, and health. Second, the SVSC can decrease environmental pollution, food waste, and energy consumption. Third, it can improve food quality and consumers' health. Fourth, the SVSC enhances on-farm education, agricultural tourism, local livestock farming, and traditional culture and relationship. However, the SVSC encounters various barriers and challenges impeding its performances and benefits. The vegetable value chain gains several interventions and support from the government and the project to overcome these barriers. Overall, the SFSC, good agricultural practice, and sustainability are strongly associated: good agricultural practice and sustainability are inherent in the SFSC.
\end{abstract}

Keywords: short food supply chain; good practices; sustainability; vegetable; Vietnam

\section{Introduction}

The conventional agricultural production and direct exchange of food in a community have existed for a long time, especially in rural and remote regions. The modern economy, industrialization, globalization, and urbanization have generated the global (long) food supply chains (LFSCs) with several intermediaries and enhanced the industrial and intensive agricultural production. This progress has brought both positive results (e.g., productivity, production, diversity, food security, standardization) and negative impacts (e.g., health, equity, culture, environmental issues) [1-5]. The concerns of the negative influences of LFSCs have significantly increased. Fortunately, consumers have recently become more aware of the negative externalities of global and long food systems and they are willing to change their food consumption pattern by directly connecting to farmers, supporting local communities, using healthy food, and reducing the environmental impacts [6-8].

Responding to these issues, the concept of the SFSC has been developed in Europe and become a noteworthy phenomenon both from theoretical and practical perspectives $[1,2,9,10]$. While the conventional food value chains can exploit the competitive advantage, economies of scale, increase productivity, production, contribute to technology development, meet growing demand, and improve information sources [11,12], SFSCs have been established in parallel to LFSCs and can complement LFSCs to be important drivers of sustainable and equal development, diversify the sources of food supply, and reflect the characteristics of local identity, nature, health, and reliability [13-15]. 
The SFSC is contrary to the intensive agriculture model that is based on long and costly systems of processing, preserving, storing, transporting, and distributing [16]. The key characteristic of SFSCs is the capacity to re-socialize or re-spatialize food, thereby allowing consumers to assess their relative need for foods on the basis of their knowledge, experience, or perceived imagery [17]. SFSCs are usually considered with face-to-face transactions and direct links between farmers and consumers on a specific farm. SFSCs may be associated with the concepts of local food, local food systems, alternative food markets, direct sales with fewer intermediaries, and the production and distribution in a certain geographical place $[9,13,18,19]$. However, these viewpoints may leave out other types of SFSCs $[9,17,18]$. SFSCs should focus on the nature of the relationship between producers and consumers, rather than the local and spatial factors [20], hence it is important to identify criteria and define SFSCs at a larger scope.

The SFSC concept is often used as an umbrella term and there are various perspectives on the SFSC without a unique and universal definition and form $[17,21]$. The SFSC is not only the time to handle foods or distance to transport them but also the fact that products can reach the consumer embedded with value and sufficient information about the place of farming and people producing the food [17]. Generally, the SFSC concept can be identified by various criteria, such as the number of intermediaries, locality, supply chain size, percentage of direct sales, physical distance, information flow and knowledge exchange, local know-how, social relations, governance, distribution channels, and product identity related to the territory $[13,21-24]$. The different combinations of these criteria may be connected with a different degree of localness, different definitions of the SFSC, and different types of the SFSC [1].

The most recognized and cited features of the SFSC are geographical proximity and direct transaction that indicate closeness between farmers and consumers $[25,26]$. The European Commission (EU) defines the modern SFSC as a supply chain consisting of a limited number of economic actors, improving local economy, committed to cooperation, and characterized by close geographical and social relations between producers, processors, and consumers [27]. This definition can take into consideration both social proximity as well as geographical proximity, encompass both social and geographical closeness between actors [9]. The Slow Food Association [28] proposes the SFSC definition as: "A short food supply chain is created when producers and final consumers realize they share the same goals, which can be achieved by creating new opportunities that strengthen local food networks". The Association denotes that the SFSC is the vital element in empowering farmers to regain active roles in food value chains, enabling small-scale producers to establish independent food supply chains, making it easier to achieve a fair price, and building healthy local economies. Regarding distribution channels, SFSCs include pick-your-own, sales to individual consumers, internet deliveries, delivery to consumers, farmers markets, sales to small retail outlets (one intermediary) while LFSCs consist of on-farm sales to intermediaries, sales to wholesalers, sales to retail chain, and sales for processors $[22,29,30]$. However, narrow scopes of locality, markets, and products may reduce the profit of farmers and benefit of SFSCs in the modern economy and high technology era. Hence, this study broadly defines the modern SFSCs as a food value chain with six key pillars or criteria, such as short space and time, sufficient information, optimal economics, better society, environment protection, and good product quality.

SFSC can be classified into various types with criteria, such as the number of operators [2], the distances and relationship [10,17], production and distribution paradigm [16,31], market or transaction structure (individuals or collectives) [32], and the cultural background [33]. SFSCs are mainly identified by three types: (i) face-to-face: consumers directly buy foods from farmers; (ii) spatial proximity: foods are produced and retailed in the specific region of production and consumers know the local nature of the product at the retail point and spatially extended: foods are sold to consumers outside of the production location with full and transparent information for consumers $[17,18]$. SFSCs may be divided into nine categories based on the level of compromise (low, medium, and high) 
adopted by producers or consumers [21]. The classification may show the shares of power, responsibility, and benefit between producers, intermediaries, and consumers.

The EU Network for Rural Development divides SFSCs into three types on the basis of the individual or collective organizations and actors: direct sales by individuals, collective direct sales, partnerships of producers and consumers [34]. SFSCs can be separated by kinds of consumers, such as business to consumer (B2C: final consumers) and business to business (B2B: hospitals, schools, hotels, restaurants, canteens) [35]. Chiffoleau et al. [32] also categorized SFSCs by individual actors and collective actors.

Scientists and policymakers believe that SFSCs can result in positive impacts and multi-aspect benefits both for actors in value chains and local communities. The benefits of SFSCs have been proven by several studies and can be structurally summarized into (i) Environmental protection: atmosphere, water, land, biodiversity, material and energy, animal welfare, food waste, emission and pollution; (ii) Economic development: vulnerability, job creation, higher profit and income, poverty reduction, improving local economy, collective or cooperative economics, tourism and specialty products (iii) Social sustainability: decent livelihood, consumer beliefs, closer relationship, fair trade, labor rights, equity, social respect, migration, cultural diversity and preservation; (iv) Health and well-being: farmer and worker health, consumer safety and health, product quality, certification, appetite, satisfaction, and human well-being, and (v) Governance improvement: corporate ethics, accountability, participation, sufficient and transparent information, and better cooperation $[1,4,9,13,20-23,33,36-42]$.

The benefits of SFSCs encourage actors (consumers, farmers, firms) to participate in the models. SFSCs need various factors and important forces to be formed and developed. They depend on customers' behavior, farmers' attitudes, production and distribution characteristics, and the conditions of economics, politics, society, and environment $[17,33,43]$. On the consumption side, the initial idea of the SFSC was started by a group of people who wanted to consume local, ecological, organic foods and support local farmers [13]. Cembalo et al. [44] identified twenty-three food-related lifestyles impacting consumers' participation in an SFSC and the most notable factors are freshness, health, taste, organic, quality, price, self-fulfillment, social relationship, and product information. The SFSC consumers may have a more complex understanding of food quality and link the quality to social, ethical, and environmental factors, as well as the preservation of local production [45].

On the production side, the critical factors of SFSCs can be production methods, local cultural heritage and traditions, ethical relationships among actors, environmental and health concerns, logistics and distribution strategy, willingness to become less reliant on impersonal structures of production, and premium prices for typical local products [1,46-50]. The synergies between agriculture and tourism and handicraft can importantly affect SFSCs [51]. The development of SFSCs may follow a certain organizational life cycle with three phases: pre-setup, start-up and maturing. The key factors facilitating development include the vision and role of the founders, the ability of the core actors, market and political environments, motivation of members and networking [13,52]. According to Bui et al. [40], farmers in SFSCs are worried about the small scopes of the local markets and they expect to receive training in marketing, connecting to local retailers and consumers, support on product branding, and participation in the local distribution chain.

Jarzebowski et al. [21] elaborated and structured success factors into three groups, such as (i) Creation of SFSCs: product know-how and innovation, cross-learning, regulatory frameworks and government policies, specialized local business and organizational support; (ii) Product development in SFSCs: efficient application of technology or production processes, investment of time and money, technological innovations and appropriate skills, collective branding; (iii) Access to market: on-line sales, sales to local communities, sales to supermarkets, sales to HoReCa, and direct sale. Generally, Sellitto et al. [33] reviewed and summarized different causes and encouragements into nine factors of SFSCs as follows: (F1) Environmentally friend operations; (F2) Specificity of territorial brands; (F3) Direct and ethical relationships between producers and consumers; (F4) Organic pro- 
duction; (F5) Food safety and traceability; (F6) Cultural heritage; (F7) Consumer's health; (F8) Origin identification of products; and (F9) Local work, cooperation, and pride.

Vietnam has a strong advantage in vegetable and fruit production based on suitable natural conditions and low labor costs. In 2018, the country had over 1.8 million ha of vegetable and fruit production (the vegetable area is about 898 thousand ha), an annual increase of $6 \%$ in the last five years [53]. The vegetable and fruit sector has benefitted from various global trade agreements, e.g., the agreement between Vietnam and the EU. In 2018, Vietnam's vegetable and fruit export was about EUR 3.4 million. Its leading export markets were China, the EU, and the US. However, the sector faces several challenges in exporting, such as fierce competition, technical trade barriers, quality standards, quarantine, and safety regulations. Thus, most of the fresh vegetables produced in Vietnam are consumed in domestic markets [54].

Most studies indicate the benefits of SFSCs in developed countries as the forms of local markets and alternative networks with narrow limits of locality, markets, and specialty products. There is also a dearth of studies that identify barriers to and explore the success factors of the development of SFSCs in developing and transition countries. This study proposes a conceptual framework of the SFSC, assesses the SVSC in Vietnam by using the proposed model, identifies its barriers and challenges, and explores interventions and support as critical success factors by employing both qualitative and quantitative methods. The rest of the paper is divided into three sections: In Section 2, the materials and methods are described. Section 3 presents results and discussion. The conclusion and implications remarks are given in the last section.

\section{Materials and Methods}

\subsection{Research Framework and Equations}

The general research framework can be shown in Figure 1 and explained as follows: First, a structural literature review is used to propose a conceptual framework of SFSCs with different pillars and factors. Second, primary data is collected by semi-structured farmer interviews, in-depth expert interviews, and a focus group. Third, primary quantitative and qualitative data are cleaned, analyzed, and coded by using the value chain model, the proposed framework of SFSCs, and the qualitative process. Finally, the results are consolidated, presented, and discussed.

The vegetable value chain was analyzed by using the value chain model and approach of Hoang [29], M4P [55], and Tran et al. [56]. The model and approach analyze an agricultural value chain in various social and economic aspects, including mapping the value chain and statistical description; governance (coordination, regulation, control); social interaction (relationship, linkage, trust); upgrading the value chain (knowledge, skill, technology, support); cost-profit analysis; added-value, income, and employment analysis. The economic indicators are calculated by employing the equations in Table 1. The conceptual framework of SFSCs with six pillars and 28 indicators is proposed and specifically presented in Section 3.1. The qualitative process includes four stages of coding, classifying, structuring, and synthesizing.

Table 1. Equations to calculate the economic indicators.

\begin{tabular}{cc}
\hline Indicators & Calculation \\
\hline Revenue $(\mathrm{P})$ & Output $\times$ Unit price \\
Total cost & Variable cost + Fixed cost \\
Fixed cost & Maintenance cost + Depreciation cost + Management cost + Tax + Interest \\
Variable cost & Input costs + Wage + Transportation cost + Power cost \\
Intermediate cost (IC) & Input costs + Material costs + Fuel cost (pay to intermediate goods suppliers) \\
Added value (VA) & Revenue-Intermediate cost \\
\hline
\end{tabular}


Table 1. Cont.

\begin{tabular}{cc}
\hline Indicators & Calculation \\
\hline Gross profit (GP) & VA-(Wage + Interest + Tax + Maintenance, Rent cost, Transportation costs) \\
Net Profit (NPr) & GP-Depreciation cost \\
Income & $\mathrm{NPr}+$ Own wage (household labor) \\
\hline
\end{tabular}

Source: Own construction based on Hoang [29], M4P [55], and Tran et al. [56].

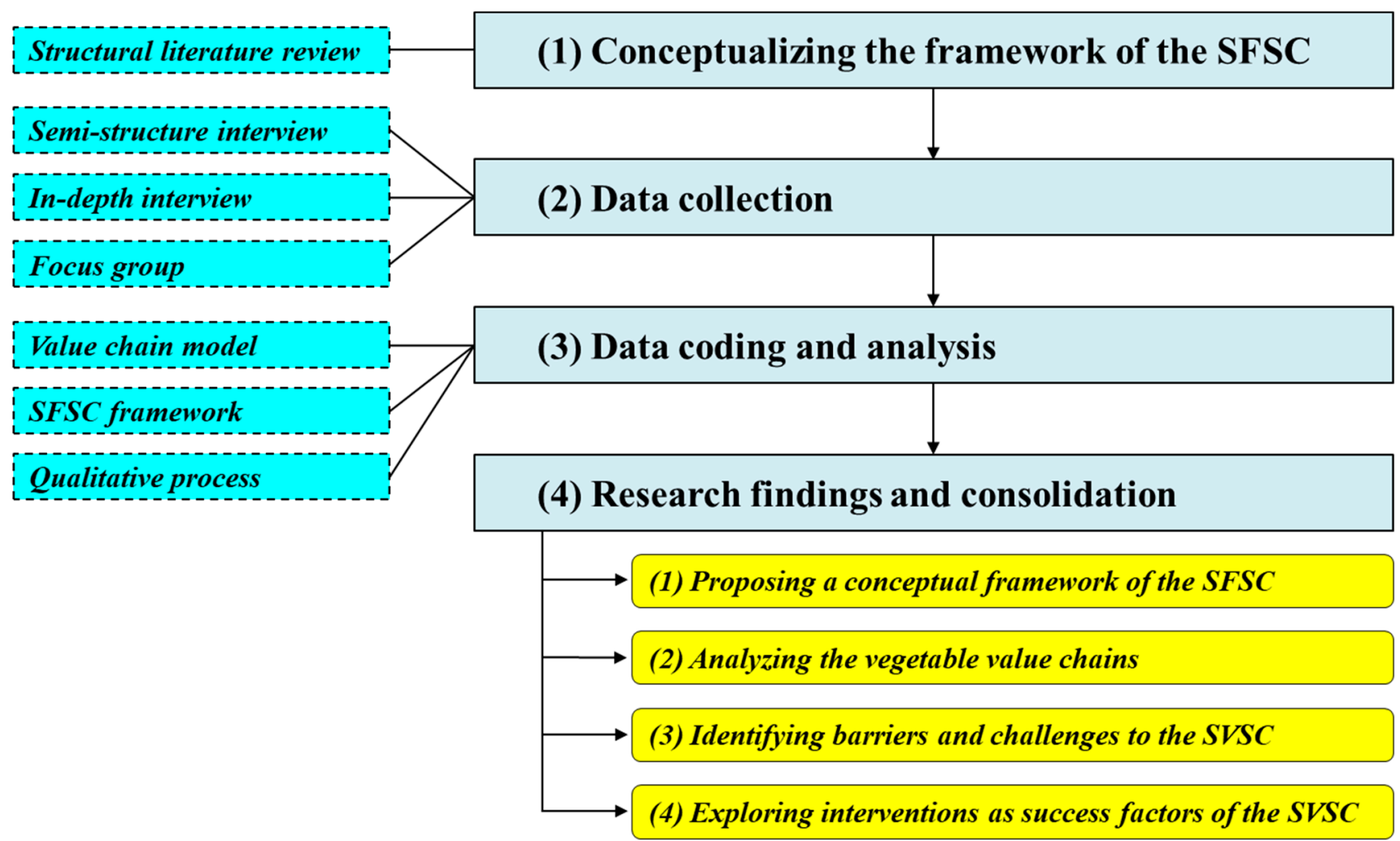

Figure 1. The research framework. Source: Own construction.

\subsection{Data Collection}

The primary data was collected in 2019 via semi-structured questionnaires to assess the short vegetable value chain and in-depth expert interviews to explore the benefits, barriers, and key success factors of the SVSC. Semi-structured farmer interviews were fulfilled with 68 vegetable producers, including 16 SVSC farmers and 52 conventional farmers. The authors used convenience sampling based on the total number of SFSC farmers in the project (most SVSC farmers) and conventional farmers in the area. Farmers were asked to provide data on four parts: (i) The characteristics of the farm, household, product, and production (for statistical analysis); (ii) Contract, coordination, and market information; (iii) Supporting projects and policies; and (iv) Opportunities, challenges, and open questions. In-depth expert interviews were used with 25 stakeholders, i.e., farmers, cooperative directors, firm leaders, consumers, project officers, and government officers with exploratory questions on the SVSC, its benefits and barriers, and potential interventions and support as key success factors. In-depth interviews lasted about 60 minutes on average and covered stakeholders across the SVSC. In addition, a focus group with key stakeholders was conducted for qualitative analysis and consolidating the findings.

The study area is about $100 \mathrm{~km}$ from the area to Ho Chi Minh City, the central food market of Vietnam. The location has a long tradition, experience, and a strong advantage in vegetable production, cattle-breeding, and aquatic products. The waste and by-products of animal husbandry and aquatic product processing are the important inputs and factors for 
vegetable crops, especially good practice and organic vegetable production. The location has been supported by the Seed to Table project, funded by the Government of Japan, which aimed to develop good practice and organic vegetable production, conserve the natural resources and the cultural heritage, and connect rural food producers with urban consumers [57].

\section{Results and Discussion}

\subsection{Proposing Conceptual Framework of the SFSC}

The economics literature shows various definitions, criteria, types, and key success factors of SFSCs. Locality and specialty product gain the greatest attention in most studies. However, narrow scopes of locality, market, and specialty product may decrease the profit for farmers and the benefits of SFSCs with the rapid development of the modern economy and high technology. Hence, this study defines and measures SFSCs, at larger scopes, as a food value chain that can satisfy six key pillars/criteria and 28 factors/indicators by employing the structural literature review and qualitative process. The conceptual SFSC framework is proposed and illustrated as follows (Figure 2): (1) Space \& Time: short distance, short time, pre-processing, and no preservation or preservative; (2) Information: label, traceability, communication, and appearance or display; (3) Economics: price, profitability, employment, income, and local development; (4) Society: health, relationship, linkage, fairness, trust, and culture; (5) Environment: production pollution, water usage, energy usage, and food waste; (6) Quality: freshness, safety, taste, certification, and specialty. A food value chain that can meet more criteria and factors at higher degrees may indicate the more developed and effective SFSC. The indicators in the SFSC framework can be assessed by both quantitative and qualitative measurements with different scales: nominal, ordinal, interval, and ratio.

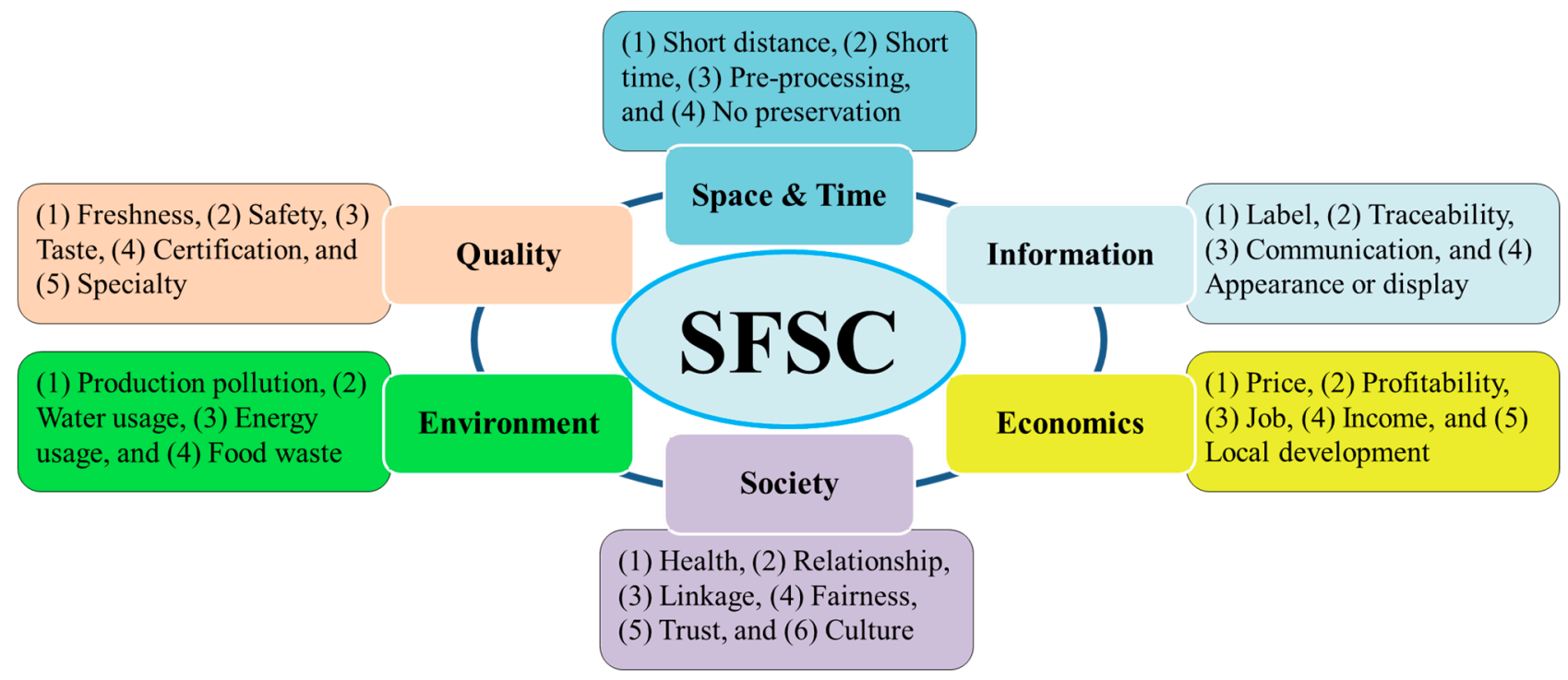

Figure 2. The framework of SFSCs. Source: Own construction based on literature review.

\subsection{Assessing the Short Vegetable Supply Chain}

3.2.1. Analyzing the Vegetable Value Chain

Descriptive statistics of vegetable households: The survey area is in the Ben Tre province of Vietnam. The location has a long tradition and natural advantage in agricultural products, such as coconut, pomelo, vegetables, fishery, and animal husbandry. However, most vegetable farms have small and very small scales with an average area of 0.28 ha per household and 0.11 ha per worker. Vegetable farmers are usually low educated with an average school time of eight years and relatively old with an average age of 50 years old. They have a long vegetable production experience, with an average experience of 23 years. 
The farmers mainly use household labor for vegetable production. Most farming lands are alluvial and gray soils that are good for vegetable production, whereas some fields also face salinity intrusion and pollution problems (Figure 3). Interestingly, 39\% of vegetable farms are near rivers, important traffic in the rural area, while only $7 \%$ of vegetable farms are near truck roads (Figure 3).
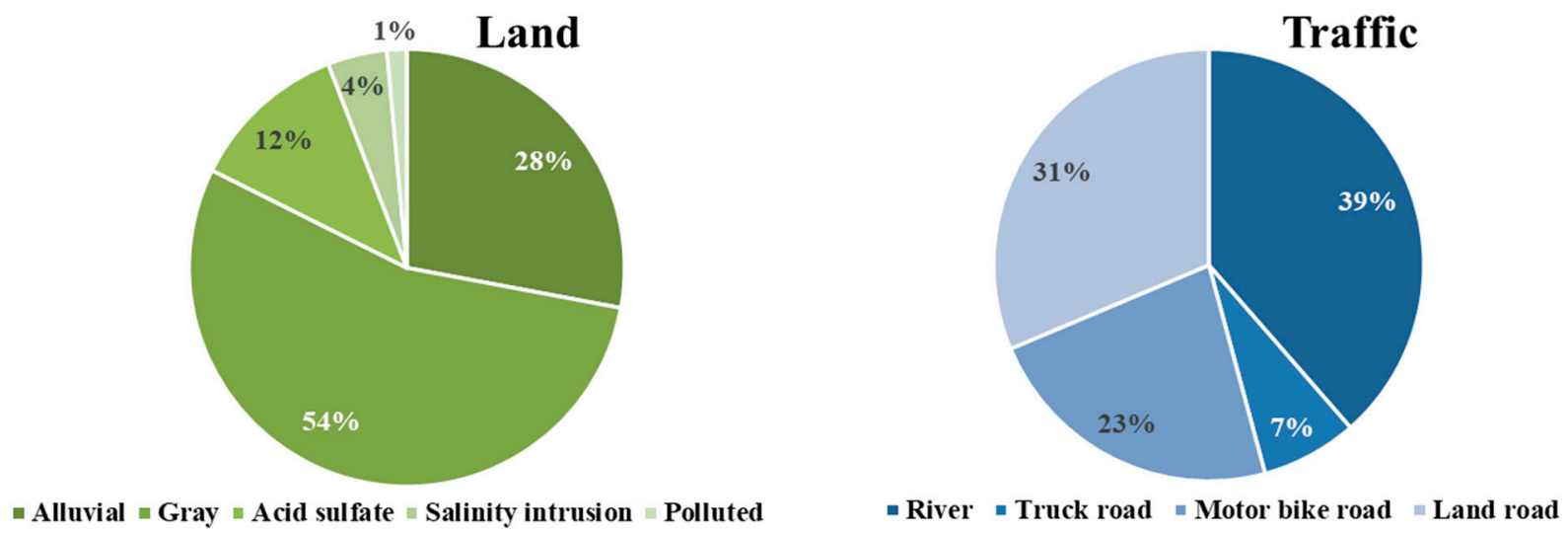

Figure 3. The land and traffic characteristics of vegetable farms. Source: Own analysis.

Diagram of the vegetable value chain: There are two vegetable value chains in Ben Tre, the short vegetable supply chain and the conventional vegetable supply chain (CVSC). The SVSC has three actors, such as farmers, retailers, and consumers while the CVSC may include several participants, such as farmers, local traders, wholesalers, retailers, and consumers (Figure 4). In the SVSC, the products are delivered to consumers through two channels. First, farmers sell vegetables to retailers and retailers sell the products to users (one intermediary). The retailers have linkages and marketing contracts with farmers. This flow accounts for $65 \%$ of the total quantity. Second, farmers sell vegetables to consumers at farms, online, or in farmer markets (no intermediary). The farmer markets are usually organized in Ho Chi Minh City at the weekends or planned days for direct meetings between farmers and consumers (known as Happy and Green Markets). This flow accounts for $35 \%$ of the total volume.

There are various channels with several actors and intermediaries in the conventional vegetable value chain (Figure 4). First, the vegetable products are mainly traded through local traders, wholesalers, and retailers (three intermediaries) before being sold to consumers. This flow accounts for over $75 \%$ of the total vegetable production of the CVSC. Vegetable producers also provide products to retailers and directly to consumers with smaller proportions, $10 \%$ and $5 \%$ respectively. Usually, there are no linkages and marketing contracts in the conventional vegetable value chain.

The SVSC has been built and developed on the basis of support from the Seed to Table project and the local government. In the SVSC, products are harvested, pre-processed, packaged, labeled, and delivered to retailers or consumers through the process in Figure 5. First, farmers uproot vegetables, cut roots, and perform other harvesting activities (depending on vegetable types). Second, the products are pre-processed by washing, cleaning, and classifying. The loss ratio is about $10-15 \%$. Third, the vegetables are packaged according to the regulations of the project and certifications. Fourth, the products are labeled with sufficient information as regulated by the project and certifications; logo of the project, firms and certifications; brands and names of producers. Fifth, the vegetable products can be delivered to retailers and consumers at farms, bus stations (third transport parties), or/and farmer markets. 


\section{Short Supply Chain Conventional Supply Chain}

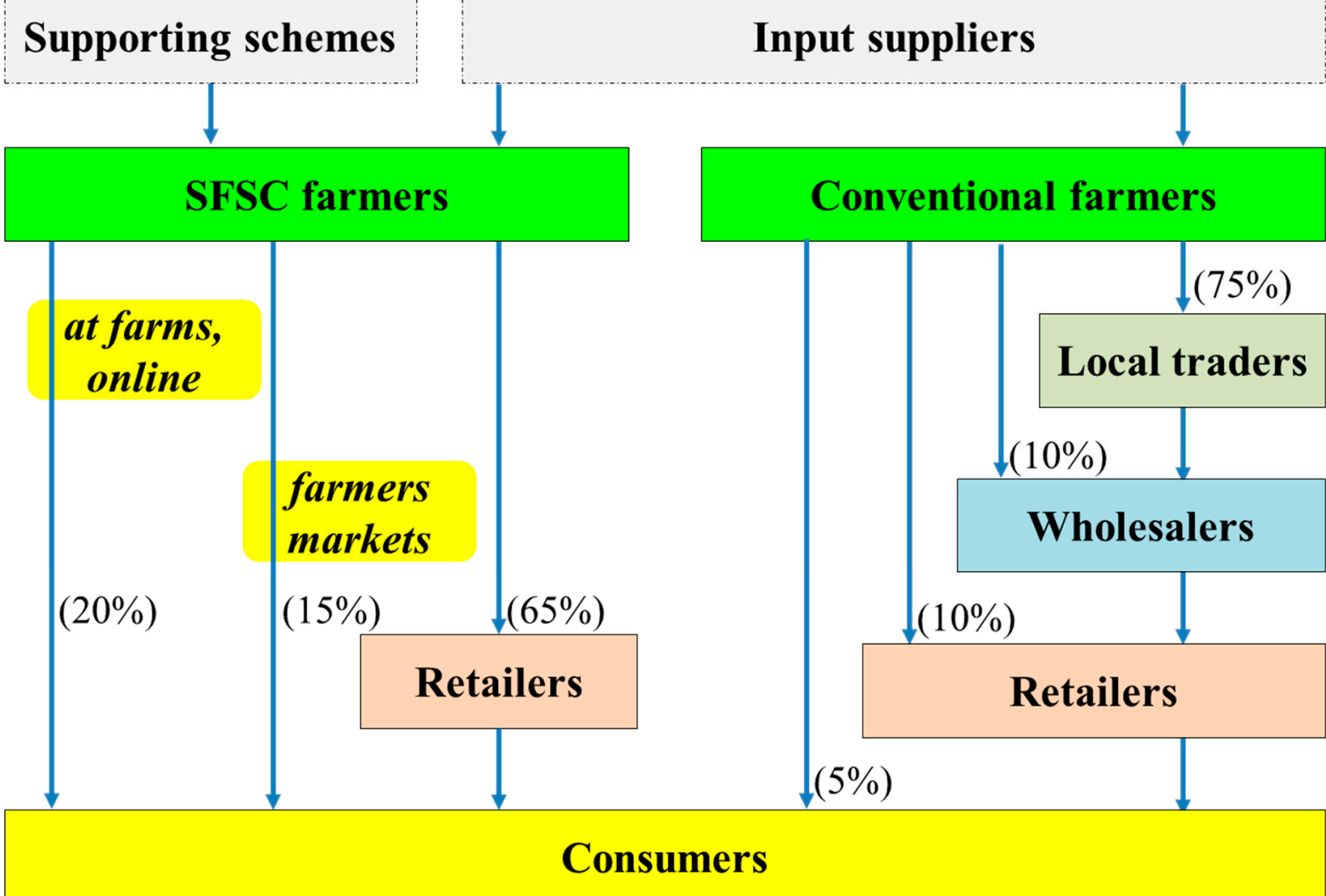

Figure 4. The diagram of the SVSC and the CVSC. Source: Own construction.

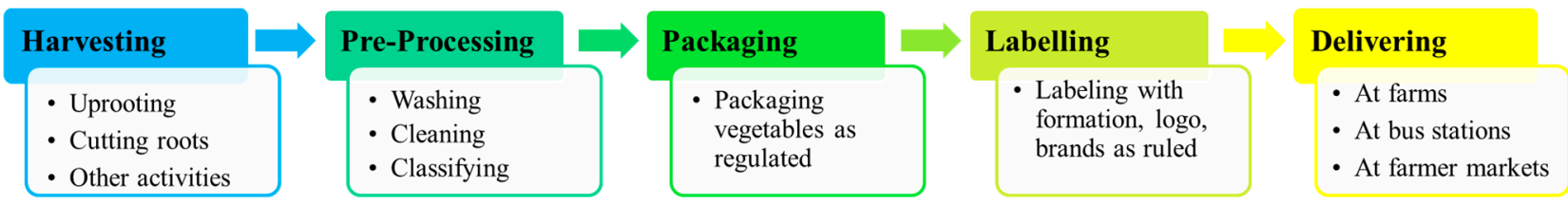

Figure 5. The product flow in the SVSC. Source: Own construction.

In the next sections, the criteria and factors of the short vegetable value chain in the Ben Tre province of Vietnam are assessed by employing the proposed framework of SFSCs in Section 3.1. with six pillars and 28 indicators.

\subsubsection{Space and Time}

The location for this SVSC study is an area about $35 \mathrm{~km}$ from Ben Tre city, the main local market, and $100 \mathrm{~km}$ from Ho Chi Minh City, the biggest vegetable market. The distance to Ben Tre city is shorter than the average scope in the UK's SFSCs, about $48 \mathrm{~km}$ [58]. Though the distance to Ho Chi Minh City is longer, the vegetable delivery does not take much time, about three hours. Within the time, the products are still fresh without further processing or special preservation. This vegetable value chain has only one intermediary of retailers. Hence, the vegetable value chain to Ho Chi Minh city can be considered as the SFSC. If the market is restricted in the locality of Ben Tre, the vegetable price, the farmers' profit, and the benefit of the SVSC greatly reduce. 


\subsubsection{Information}

In the SVSC, the products are officially packaged and labeled under the regulation of the project, the government, and firms with sufficient information about the product, producer, brand, certification, traceability, and others. The appearance and display of the vegetables additionally indicate the quality information of the product. With support from the project and the government, the product quality, social values, and environmental benefits of the SVSC are well communicated to consumers and communities. Recently, information and communication between farmers and consumers have been strongly enhanced and developed thanks to social networks (e.g., Facebook, Zalo, others), online shopping, and information technology. Therefore, the indicators of information criteria of the SVSC are well satisfied within SFSCs [17,59].

\subsubsection{Economics}

The economic benefit is a key factor of SFSCs. The cost and benefit analysis and comparison of the short vegetable value chain and the conventional value chain generally show that the SVSC can generate higher economic benefits to the producers and the local economy than those of the CVSC (Table 2). The producers in the SVSC can gain 114\% higher prices, 32\% higher net profits, and 39\% higher incomes in comparison with those farmers in the CVSC. If the farmers can utilize their sources of organic fertilizers from animal waste, they can gain $48 \%$ higher incomes than those farmers in the CVSC. Farmers' income includes net profit and wage for household labor. The vegetable production in the SVSC needs much more labor than that in the CVSC. In other words, the SVSC can provide more employment and income to farmers and locality. These findings are supported by previous studies $[1,2,4,60]$ and contribute to agricultural economic literature.

Table 2. Cost and benefit analysis of vegetable productions per ha in the SVSC and the CVSC.

\begin{tabular}{cccccc}
\hline No. & Items & Unit & SVSC & CVSC & Comparison \\
\hline 1 & Price & EUR/Kg & 0.57 & 0.27 & $114 \%$ \\
2 & Productivity & Kg/Ha & 20,000 & 30,000 & $-33 \%$ \\
3 & Turnover & EUR & 11,364 & 7955 & $43 \%$ \\
4 & Intermediary Cost & EUR & 873 & 456 & $91 \%$ \\
5 & Value Added & EUR & 10,491 & 7498 & $40 \%$ \\
6 & Household labor & EUR & 3182 & 2045 & $56 \%$ \\
7 & Profit & EUR & 7178 & 5396 & $33 \%$ \\
8 & Net profit & EUR & 7121 & 5379 & $32 \%$ \\
9 & Income & EUR & 10,303 & 7424 & $39 \%$ \\
\hline
\end{tabular}

Source: Own calculation.

\subsubsection{Society}

The vegetables in the SVSC are produced and packaged under the regulations and guides of the project, firms, and the certification organization. The farmers often meet their consumers directly and they become prouder of their products and locality. Pride is an important factor in SFSCs $[61,62]$. As a result, consumer health is guaranteed and the farmers can achieve more relationships, trust, and respect from consumers. The members of a vegetable cooperative in the SVSC usually have good family relationships with each other with high trust and respect. The vegetable cooperatives also have a linkage with retail firms through official marketing contracts. Good practice and organic production in the SVSC can also protect the health of farmers and workers. Vegetable producers in the SVSC is also associated with the activities of on-farm education, agricultural tourism, and handicraft. This means that the SVSC can include the social criteria of SFSCs $[51,63,64]$. However, cultural heritage seems to be the weakest factor in this SVSC.

\subsubsection{Environment}

Environmental sustainability is one of the greatest contributions achieved by SFSCs. In this SVSC, good practice and organic production can reduce production pollution 
due to the utilization of organic fertilizers and pesticides. Good practice and organic agricultural production methods can increase biodiversity and soil quality. Water can be more efficiently used for vegetable production. With short distances and time to transport and deliver without preservation and storage, the SVSC uses less energy, vegetable wastes are minimized, and emissions are significantly reduced. The environmental sustainability of SFSCs has been widely proven in developed markets $[9,21,22,65]$.

\subsubsection{Quality}

The vegetable products in the SVSC are produced according to good practice or organic processes, hence the SVSC can meet the criteria of safety, taste, and certification. The vegetables are still fresh and good-quality with the short distance and time to deliver. Consumers usually purchase these vegetables in the SVSC due to the product quality and sufficient information that can make them trust and protect their health. This result consolidates the findings of Gonzalez-Azcarate et al. [66]. However, the vegetables in this SVSC are popular and common products without know-how and specialty. This is relatively different from some statements in previous studies [61,67].

In general, the SVSC in the study can successfully meet the criteria, definitions, and factors of a short food supply chain. The SVSC can result in various social, economic, and environmental benefits to farmers, consumers, and locality. The findings validate that the search for economic benefit is not opposed to a rationale of environmental and social sustainability as stated in Enjolras and Aubert [68] by the design of SFSCs. These aspects can effectively complement and enhance each other. However, the SVSC has encountered various barriers and its success is dependent on many critical factors.

\subsection{Barriers to the Short Vegetable Value Chain}

In general, SFSCs may face various barriers and challenges, especially in planning and building periods, which can impede the development and benefits of SFSCs. In some cases, barriers and challenges could cause the failures and the endings of the SFSC schemes and models. In this study, the SVSC has encountered both internal barriers and external challenges. They can be identified and summarized as follows:

Weak farmer capacity: The vegetable farmers in the SVSC have low education and poor knowledge of modern food production and distribution. They may have much experience and skill in producing vegetables by conventional methods, however, their knowledge and skill in good agricultural practices and modern short supply chains are short. Moreover, farmers' old habits and awareness are notable challenges to good practices and short value chains.

Low-quality land and small-scale farm: The farmers have employed the conventional production methods in their fields for a long time, thus the quality of the vegetable land has been reduced and the soil has been polluted with chemical fertilizers and pesticides. Additionally, the vegetable farms in the area are small or very small. Low-quality land and small-scale farms can cause difficulties in utilizing high technology, applying good agricultural practices, and developing modern short food supply chains.

High cost and price: The application of good agricultural practices, especially organic method, requires more investment in equipment, land renovation, more labor, and other expensive inputs while it cannot accept intensive cultivation, chemical fertilizers, and chemical pesticides. These issues lead to the increase in production cost and a decrease in crop productivity, and finally high prices.

Small output markets: High prices and specialty products make the market segments for the good practice and organic vegetables in the SVSC narrow. In addition, the product distribution systems are restricted within short supply chains, thus consumers' access to the vegetable products is limited and difficult. Therefore, output markets for the vegetables in the SVSC are small and difficult to assess.

Poor cooperation: The cooperation between farmers in vegetable cooperatives or between farmers and other actors in the value chain is generally weak and unstable due to 
the old habits, low commitments, and the obsession with the old concept of cooperatives (cooperative economy) in Vietnam. Several farmers and actors make decisions based on relationships rather than official contracts. They prefer instant profits rather than sustainable and long-term benefits.

Deficient capital resources: The application of good agricultural practices and participation in the modern SVSC need significant capital resources to invest in equipment, land renovation, machines, information technology (e.g., smartphone, internet), and other inputs. However, most vegetable farmers are small and poor households. Thus, weak capital resources are also the main barriers to building and developing the SVSC.

Climate change: Climate change is a big challenge to the world in general and has recently become a considerable problem in Ben Tre province of Vietnam. Ben Tre is in the Mekong River Delta. The area is nearby the sea. It has been formed by alluvial deposits from the Mekong River that, however, has currently been restricted by the construction of various hydroelectric dams in China, Thailand, Laos, and Cambodia. More specifically, salinity intrusion, sea-level rise, drought, and soil degradation are increasing challenges to the short vegetable value chain.

\subsection{Interventions and Support as Success Factors}

The SVSC has encountered various barriers and challenges impeding its creation, development, and benefit. For these reasons, there is great demand for diverse interventions and support for such initiatives, especially in the starting phase. The survey shows that the interventions and support from the Seed to Table project and the local government played essential roles in building and developing the SVSC. These interventions and support may be summarized and presented as follows:

Establishing cooperatives: In general, Vietnamese farmers are commonly hesitant to participate in agricultural cooperatives due to the obsession with the old concept of cooperative, preferring spot and free transactions, and insufficient awareness of cooperatives' principles and benefits. With the training and support from the project and the government, vegetable cooperatives (or groups) have been established and grown. This is one of the vital steps in forming and developing the SVSC.

Enhancing farmer capacity and certificating: The farmers participating in vegetable cooperatives and the SVSC can receive various training and coaching activities, such as seed selection, planting and taking care of vegetables, making and using organic fertilizers, producing and using organic pesticides, tracking and reporting production processes, harvesting, and packaging according to good practice standards. Moreover, the farmers are monitored by the project and firms to ensure that their products meet the quality and safety standards.

Providing capital support: Farmers in the vegetable cooperatives and the SVSC can gain capital support, such as seed, equipment and tools, technology, inputs, and a loan from the project and the government. The capital support is just enough for farmers to have sufficient resources to start their vegetable production with good agricultural practice standards in the SVSC.

Promoting communication and information: The cooperatives, the farmers, and the SVSC can benefit from the communication and information promotion activities of the project, the government, and other organizations. First, farmers can use logos and brands of the project and firms. Second, they are provided with professional label designs with sufficient information. Third, the vegetable farmers can directly meet consumers in farmer markets. Finally, farmers can benefit from the project's public media and communication activities.

Linking to markets: Small-scale and individual farmers always face difficulties selling agricultural products at profitable prices, especially in developing markets like Vietnam. In this SVSC, the vegetable products are successfully linked to the market through contracts with retail firms, farmer markets, and other direct connections with consumers at farms 
and online. The farmers can sell out their products at relatively high prices and obtain good profitability.

Combining with other activities: Notably, the SVSC can be associated with on-farm education, on-farm tourism, the traditional culture, and the local cattle-breeding production systems with support from the project and the local government. Pupils and tourists can come to the vegetable fields and "work as farmers" to experience and learn. These activities can promote communication and information exchange between farmers and consumers and make people aware of good agricultural production, local products, environmental protection, and health issues. Vegetable production, contained the local livestock industry can both increase farmers' income and protect the environment.

\section{Conclusions}

The rapid increases in environmental pollution, urbanization, health concern, and technological progress enhance the need for greener, healthier, and fairer food production and consumption. Consumers have been more aware of the negative externalities of the long food systems and willing to change their food consumption pattern by directly connecting to farmers, supporting local communities, using healthy food, and reducing the environmental impact. The SFSC model emerges and becomes the vital solution for these issues. This study aims to propose a conceptual SFSC framework, assess the short vegetable value chain in Vietnam, identify the barriers and challenges, and explore interventions and support as key success factors of the SVSC.

Narrow limits of locality, markets, and products may reduce the profits of farmers and the benefits of SFSCs with the rapid development of the modern economy and high technology. Hence, this study broadly defines the modern SFSC as a food value chain with six key pillars: short space and time, sufficient information, optimal economics, better society, environment protection, and good product quality. There are 28 indicators of the SFSC model within these pillars. The definition can encompass different aspects of both food production and the food market. The SFSC framework can be utilized to assess the benefit, sustainability, and effectiveness of SFSCs in different contexts.

The vegetable value chain in Vietnam is analyzed and mapped. The survey shows that the vegetable farms are small and separated. Farmers are usually low educated and relatively old. The soil of the area is advantageous for vegetable production, but it is degrading. There are two vegetable value chains in the location, which are the SVSC and the CVSC. The authors use the proposed SFSC framework to assess the short vegetable supply chain. The findings show that the SVSC can effectively perform, meet the criteria of the SFSC, and bring various social, economic, and environmental benefits to the farmers, the communities, and consumers. First, it can increase farmers' income, employment, fairness, and health. Second, the SVSC can decrease environmental pollution, food waste, and energy consumption. Third, the chain can improve food quality and consumer health. Fourth, the SVSC enhances on-farm education, agricultural tourism, local livestock farming, and traditional culture and relationships.

Though the SVSC can result in various benefits, it has encountered several internal barriers and external challenges, including weak farmer capacity, low-quality land and small-scale farms, high cost and price, small output markets, poor cooperation, deficient capital resources, and climate change. To overcome these barriers and develop the SVSC, the local government and the Seed to Table project have provided many interventions and support, such as: establishing cooperatives, enhancing farmer capacity and certificating, providing capital support, promoting communication and information, linking farmers to markets, and combining with other activities, such as on-farm education, on-farm tourism, traditional culture, and local cattle. Overall, the short food value chain, good agricultural practice, and sustainability are strongly and positively associated: good agricultural practice and sustainability are inherent in the short food supply chain.

This study successfully proposed a conceptual framework of the SFSC, assessing the SFSC in a developing country, identifying barriers and challenges to the SVSC, and 
exploring the interventions and support as critical determinants of the SVSC. However, it could not measure the quantitative dimensions of all indicators in the SFSC, particularly social and environmental aspects. Additionally, it did not quantitatively identify the determinants of these variables. Thus, research that focuses on measuring the quantitative dimensions of the SFSC indicators and identifying the determinants of the SFSC will add to this study. In addition, the study of a systematic literature review that can compare different indicators of SFSCs will make a significant theoretical contribution to the short food supply chain literature. Despite these limitations, this research can contribute to the existing literature and create opportunities for future studies on SFSCs, good agricultural practices, cooperatives, and sustainability. The schemes of SFSCs should be expanded and applied in other contexts to gain multidimensional sustainability outcomes.

Funding: This research was funded by the University of Economics Ho Chi Minh City (UEH).

Institutional Review Board Statement: Not applicable.

Informed Consent Statement: Not applicable.

Data Availability Statement: Not applicable.

Conflicts of Interest: The author declare no conflict of interest.

\section{References}

1. Paciarotti, C.; Torregiani, F. The logistics of the short food supply chain: A literature review. Sustain. Prod. Consum. 2021, 26, 428-442. [CrossRef]

2. De Fazio, M. Agriculture and Sustainability of the Welfare: The Role of the Short Supply Chain. Agric. Agric. Sci. Procedia 2016, 8 , 461-466. [CrossRef]

3. Hoang, V.V.; Tran, K.T. Comparative advantages of alternative crops: A comparison study in Ben Tre, Mekong Delta, Vietnam. AGRIS -Line Pap. Econ. Inform. 2019, 11, 35-47. [CrossRef]

4. Schmitt, E.; Galli, F.; Menozzi, D.; Maye, D.; Touzard, J.-M.; Marescotti, A.; Six, J.; Brunori, G. Comparing the sustainability of local and global food products in Europe. J. Clean. Prod. 2017, 165, 346-359. [CrossRef]

5. Kummu, M.; de Moel, H.; Porkka, M.; Siebert, S.; Varis, O.; Ward, P. Lost food, wasted resources: Global food supply chain losses and their impacts on freshwater, cropland, and fertiliser use. Sci. Total. Environ. 2012, 438, 477-489. [CrossRef] [PubMed]

6. Duram, L.A.; Cawley, M. Irish chefs and restaurants in the geography of "local" food value chains. Open Geogr. J. 2012, 5, 16-25. [CrossRef]

7. Feldmann, C.; Hamm, U. Consumers' perceptions and preferences for local food: A review. Food Qual. Prefer. 2015, 40, 152-164. [CrossRef]

8. Bloemhof, J.M.; van der Vorst, J.G.; Bastl, M.; Allaoui, H. Sustainability assessment of food chain logistics. Int. J. Logist. Res. Appl. 2015, 18, 101-117. [CrossRef]

9. Vittersø, G.; Torjusen, H.; Laitala, K.; Tocco, B.; Biasini, B.; Csillag, P.; De Labarre, M.D.; Lecoeur, J.-L.; Maj, A.; Majewski, E.; et al. Short Food Supply Chains and Their Contributions to Sustainability: Participants' Views and Perceptions from 12 European Cases. Sustainability 2019, 11, 4800. [CrossRef]

10. Aubry, C.; Kebir, L. Shortening food supply chains: A means for maintaining agriculture close to urban areas? The case of the French metropolitan area of Paris. Food Policy 2013, 41, 85-93. [CrossRef]

11. Mentzer, J.T.; Myers, M.B.; Stank, T.P. Handbook of Global Supply Chain Management; SAGE Publications, Inc.: New York, NY, USA, 2007. [CrossRef]

12. Bovet, D.; Sheffi, Y. The brave new world of supply chain management. Supply Chain Manag. Rev. 1998, 2, 14-22.

13. Galli, F.; Brunori, G. Short Food Supply Chains as Drivers Of Sustainable Development; Document Developed in the Framework of the FP7 Project FOODLINKS (GA No. 265287); Laboratorio di Studi Rurali Sismondi: Pisa, Italy, 2013; ISBN 978-88-90896-01-9.

14. Aguiar, L.D.C.; Delgrossi, M.E.; Thomé, K.M. Short food supply chain: Characteristics of a family farm. Rural Sociol. Cienc. Rural 2018, 48, e20170775. [CrossRef]

15. Hoang, V.; Nguyen, A.; Hubbard, C.; Nguyen, K.-D. Exploring the Governance and Fairness in the Milk Value Chain: A Case Study in Vietnam. Agriculture 2021, 11, 884. [CrossRef]

16. King, R.P.; Boehlje, M.; Cook, M.L.; Sonka, S.T. Agribusiness economics and management. Am. J. Agric. Econ. 2010, 92, 554-570. [CrossRef]

17. Marsden, T.; Banks, J.; Bristow, G. Food Supply Chain Approaches: Exploring their Role in Rural Development. Sociol. Rural. 2000, 40, 424-438. [CrossRef]

18. Renting, H.; Marsden, T.K.; Banks, J. Understanding Alternative Food Networks: Exploring the Role of Short Food Supply Chains in Rural Development. Environ. Plan. A 2003, 35, 393-411. [CrossRef] 
19. Tran, T.K.; Ho, C.V.; Le, V.G.N.; Hoang, V.V.; Nguyen, V.A.; Nguyen, V.N. Analyzing the Coconut Value Chain in Ben Tre, Vietnam; Research Project Report; University of Economics: Ho Chi Minh City, Vietnam, 2011.

20. Kneafsey, M.; Venn, L.; Schmutz, U.; Balázs, B.; Trenchard, L.; Eyden-Wood, T.; Bos, E.; Sutton, G.; Blackett, M. Short food supply chains and local food systems in the EU. A state of play of their socio-economic characteristics. JRC Sci. Policy Rep. 2013, 123, 129.

21. Jarzębowski, S.; Bourlakis, M.; Bezat-Jarzębowska, A. Short Food Supply Chains (SFSC) as Local and Sustainable Systems. Sustainability 2020, 12, 4715. [CrossRef]

22. Malak-Rawlikowska, A.; Majewski, E.; Wąs, A.; Borgen, S.O.; Csillag, P.; Donati, M.; Freeman, R.; Hoàng, V.; Lecoeur, J.L.; Mancini, M.C.; et al. Measuring the Economic, Environmental, and Social Sustainability of Short Food Supply Chains. Sustainability 2019, 11, 4004. [CrossRef]

23. Hoang, V. Impact of Contract Farming on Farmers' Income in the Food Value Chain: A Theoretical Analysis and Empirical Study in Vietnam. Agriculture 2021, 11, 797. [CrossRef]

24. Schmitt, E.; Dominique, B.; Six, J. Assessing the degree of localness of food value chains. Agroecol. Sustain. Food Syst. 2017, 42, 1-26. [CrossRef]

25. Ilbery, B.; Maye, D. Food supply chains and sustainability: Evidence from specialist food producers in the Scottish/English borders. Land Use Policy 2005, 22, 331-344. [CrossRef]

26. Kebir, L.; Torre, A. Geographical Proximity and New Short Supply Food Chains. In Creative Industries and Innovation in Europe: Concepts, Measures and Comparative Case Studies; Lazzeretti, L., Ed.; Routledge: New York, NY, USA, 2012; pp. $212-229$.

27. Augere-Granier, L.M. Short Food Supply Chains and Local Food Systems in the EU.; European Parliamentary Research Service, EPRS: Brussels, Belgium, 2016.

28. Slow Food. Available online: https://www.fondazioneslowfood.com/en/what-we-do/earth-markets/producers-and-coproducers/short-food-chain/ (accessed on 10 October 2021).

29. Hoang, V.V. Value chain analysis and competitiveness assessment of da xanh pomelo sector in Ben Tre, Vietnam. Asian Soc. Sci. 2015, 11, 8. [CrossRef]

30. Muller, P.; Böhm, M.; Csillag, P.; Donati, M.; Drut, M.; Ferrer-Pérez, H.; Gauvrit, L.; Gil, J.M.; Hoang, V.; Malak-Rawlikowska, A.; et al. Are Certified Supply Chains More Socially Sustainable? A Bargaining Power Analysis. J. Agric. Food Ind. Organ. 2020, 19, 177-192. [CrossRef]

31. Urquhart, J.; Acott, T.G. Re-connecting and embedding food in place: Rural development and inshore fisheries in Cornwall, UK. J. Rural. Stud. 2013, 32, 357-364. [CrossRef]

32. Chiffoleau, Y.; Millet-Amrani, S.; Canard, A. From Short Food Supply Chains to Sustainable Agriculture in Urban Food Systems: Food Democracy as a Vector of Transition. Agriculture 2016, 6, 57. [CrossRef]

33. Sellitto, M.; Vial, L.A.M.; Viegas, C.V. Critical success factors in Short Food Supply Chains: Case studies with milk and dairy producers from Italy and Brazil. J. Clean. Prod. 2018, 170, 1361-1368. [CrossRef]

34. Peters, R. (Ed.) Local Food and Short Supply Chains. EU Rural Review; European Network for Rural Development: Brussel, Belgium, 2012.

35. Bertazzoli, A.; Ruggeri, A.; Samoggia, A. Short supply chain: Analysis of the competitiveness of organic horticultural farmers at Italian regional level. In Proceedings of the 118th Seminar of the EAAE: Rural Development: Governance, Policy Design and Delivery, Ljubljana, Slovenia, 25-27 August 2010; pp. 771-783.

36. Cleveland, D.A.; Carruth, A.; Mazaroli, D.N. Operationalizing local food: Goals, actions, and indicators for alternative food systems. Agric. Hum. Values 2014, 32, 281-297. [CrossRef]

37. Canfora, I. Is the Short Food Supply Chain an Efficient Solution for Sustainability in Food Market? Agric. Agric. Sci. Procedia 2016, 8, 402-407. [CrossRef]

38. Dunay, A.; Lehota, J.; Macsai, E.; Illes, C.B. Short supply chain: Goals, objectives and attitudes of producers. Acta Polytech. Hung. 2018, 15, 199-217.

39. El Hage, N. Guidelines for Sustainability Assessment in Food and Agriculture; Food and Agriculture Organization of the United Nations: Rome, Italy, 2012.

40. Bui, T.; Nguyen, A.; Le, T.; Nguyen, V.; Le, T.; Tran, T.; Nguyen, N.; Le, T.; Nguyen, T.; Nguyen, T.; et al. Can a Short Food Supply Chain Create Sustainable Benefits for Small Farmers in Developing Countries? An Exploratory Study of Vietnam. Sustainability 2021, 13, 2443. [CrossRef]

41. Mundler, P.; Laughrea, S. The contributions of short food supply chains to territorial development: A study of three Quebec territories. J. Rural. Stud. 2016, 45, 218-229. [CrossRef]

42. Ochoa, C.Y.; Matarán, A.; Olmo, R.M.; López, J.M.; Fuentes-Guerra, R. The Potential Role of Short Food Supply Chains in Strengthening Periurban Agriculture in Spain: The Cases of Madrid and Barcelona. Sustainability 2019, 11, 2080. [CrossRef]

43. D’amico, M.; di Vita, G.; Chinnici, G.; Pappalardo, G.; Pecorino, B. Short food supply chain and locally produced wines: Factors affecting consumer behavior. Ital. J. Food Sci. 2014, 26, 329.

44. Cembalo, L.; Lombardi, A.; Pascucci, S.; Dentoni, D.; Migliore, G.; Verneau, F.; Schifani, G. "Rationally local": Consumer participation in alternative food chains. Agribusiness 2015, 31, 330-352. [CrossRef]

45. Lombardi, A.; Migliore, G.; Verneau, F.; Schifani, G.; Cembalo, L. Are "good guys" more likely to participate in local agriculture? Food Qual. Prefer. 2015, 45, 158-165. [CrossRef] 
46. Brown, J.; Kothari, A. Traditional agricultural landscapes and community conserved areas: An overview. Manag. Environ. Qual. Int. J. 2011, 22, 139-153. [CrossRef]

47. Roskruge, N. Traditional Māori horticultural and ethnopedological praxis in the New Zealand landscape. Manag. Environ. Qual. Int. J. 2011, 22, 200-212. [CrossRef]

48. Guzmán, G.I.; López, D.; Román, L.; Alonso, A.M. Participatory Action Research in Agroecology: Building Local Organic Food Networks in Spain. J. Sustain. Agric. 2012. [CrossRef]

49. Dowd, K.; Burke, K.J. The influence of ethical values and food choice motivations on intentions to purchase sustainably sourced foods. Appetite 2013, 69, 137-144. [CrossRef] [PubMed]

50. Conner, D.; Colasanti, K.; Ross, R.B.; Smalley, S.B. Locally Grown Foods and Farmers Markets: Consumer Attitudes and Behaviors Sustainability 2010, 2, 742-756. [CrossRef]

51. Rong, A.; Akkerman, R.; Grunow, M. An optimization approach for managing fresh food quality throughout the supply chain. Int. J. Prod. Econ. 2011, 131, 421-429. [CrossRef]

52. Schmid, O.; Hamm, U.; Richter, T.; Dahlke, A. A Guide to Successful Organic Marketing Initiatives; Research Institute of Organic Agriculture (FiBL): Frick, Switzerland, 2004.

53. General Statistics Office of Vietnam (GSO). Socio-Economic Situation Report. Available online: https://www.gso.gov.vn/nonglam-nghiep-va-thuy-san/ (accessed on 18 November 2020).

54. Nguyen, H.N. Situation and Solutions to Increase Vietnam's Export of Fruits And Vegetables. Industry and Trade Magazine. Available online: https: / tapchicongthuong.vn/bai-viet/thuc-trang-va-giai-phap-phat-trien-xuat-khau-mat-hang-rau-qua-vietnam-69215.htm (accessed on 18 November 2020).

55. M4P. Making Value Chains Work Better for the Poor: A Tool-Book for Practitioners of Value Chain Analysis, 3rd ed.; Making Markets Work Better for the Poor (M4P) Project, UK Department for international Development (DFID); Agricultural Development International: Phnom Penh, Cambodia, 2008.

56. Tran, T.K.; Ho, C.V.; Le, V.G.N.; Nguyen, V.A.; Hoang, V.V.; Nguyen, V.N. Estimate of financial benefits from value chain of Ben Tre coconut. J. Econ. Dev. 2013, 147-160. [CrossRef]

57. Seed to Table. From Seed to Table. Available online: http://seed-to-table.org/english.html (accessed on 10 October 2020).

58. Little, J.; Ilbery, B.; Watts, D.; Gilg, A.; Simpson, S. Regionalization and the rescaling of agro-food governance: Case study evidence from two English regions. Politi. Geogr. 2012, 31, 83-93. [CrossRef]

59. Allegra, V.; Bellia, C.; Zarbà, A.S. The logistics of direct sales: New approaches of the EU. Ital. J. Food Sci. 2014, 26, 443-450.

60. Hilal, M.; Leedon, G.; de Labarre, M.D.; Antonioli, F.; Boehm, M.; Péter, C.; Donati, M.; Drut, M.; Ferrer-Pérez, H.; Gauvrit, L.; et al. Organic and Geographical Indication Certifications' Contributions to Employment and Education. J. Agric. Food Ind. Organ. 2020, 19, 161-176. [CrossRef]

61. Bravo, C.P.; Cordts, A.; Schulze-Ehlers, B.; Spiller, A. Assessing determinants of organic food consumption using data from the German National Nutrition Survey II. Food Qual. Prefer. 2013, 28, 60-70. [CrossRef]

62. Clarke, N.; Cloke, P.; Barnett, C.; Malpass, A. The spaces and ethics of organic food. J. Rural. Stud. 2008, 24, 219-230. [CrossRef]

63. Thomas-Francois, K.; von Massow, M.; Joppe, M. Service-oriented, sustainable, local food value chain-A case study. Ann. Tour. Res. 2017, 65, 83-96. [CrossRef]

64. Seyfang, G. Ecological citizenship and sustainable consumption: Examining local organic food networks. J. Rural. Stud. 2006, 22, 383-395. [CrossRef]

65. Drut, M.; Antonioli, F.; Böhm, M.; Brečić, R.; Dries, L.; Ferrer-Pérez, H.; Gauvrit, L.; Hoàng, V.; Steinnes, K.K.; Lilavanichakul, A.; et al. Foodmiles: The Logistics of Food Chains Applied to Food Quality Schemes. J. Agric. Food Ind. Organ. 2020, 19, 127-143. [CrossRef]

66. González-Azcárate, M.; Maceín, J.L.C.; Bardají, I. Why buying directly from producers is a valuable choice? Expanding the scope of short food supply chains in Spain. Sustain. Prod. Consum. 2021, 26, 911-920. [CrossRef]

67. Dubois, A. Translocal practices and proximities in short quality food chains at the periphery: The case of North Swedish farmers. Agric. Hum. Values 2019, 36, 763-778. [CrossRef]

68. Enjolras, G.; Aubert, M. Short food supply chains and the issue of sustainability: A case study of French fruit producers. Int. J. Retail. Distrib. Manag. 2018, 46, 194-209. [CrossRef] 